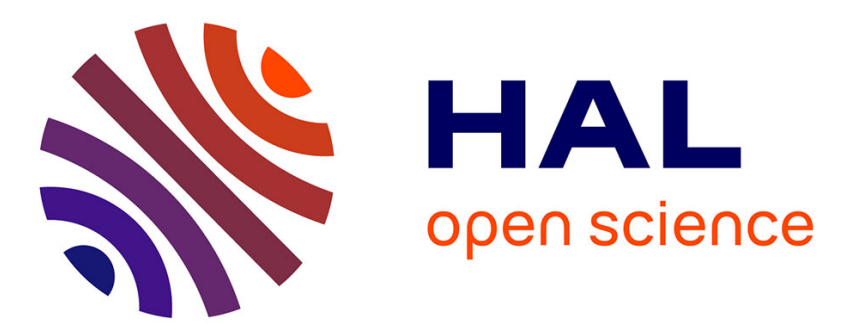

\title{
Software tools for pre- and post-processing of oceanic regional simulations.
}

Pierrick Penven, Patrick Marchesiello, Laurent Debreu, Jérome Lefèvre

\section{To cite this version:}

Pierrick Penven, Patrick Marchesiello, Laurent Debreu, Jérome Lefèvre. Software tools for pre- and post-processing of oceanic regional simulations.. Environmental Modelling and Software, 2008, 23 (5), pp.660-662. 10.1016/j.envsoft.2007.07.004 . hal-00388202

\section{HAL Id: hal-00388202 https://hal.science/hal-00388202}

Submitted on 4 Aug 2009

HAL is a multi-disciplinary open access archive for the deposit and dissemination of scientific research documents, whether they are published or not. The documents may come from teaching and research institutions in France or abroad, or from public or private research centers.
L'archive ouverte pluridisciplinaire HAL, est destinée au dépôt et à la diffusion de documents scientifiques de niveau recherche, publiés ou non, émanant des établissements d'enseignement et de recherche français ou étrangers, des laboratoires publics ou privés. 


\title{
Software tools for pre- and post-processing of oceanic regional simulations
}

\author{
Pierrick Penven ${ }^{\mathrm{a}, *}$ Patrick Marchesiello ${ }^{\mathrm{b}}$ Laurent Debreu ${ }^{\mathrm{c}}$ \\ Jérome Lefèvre ${ }^{\mathrm{b}}$

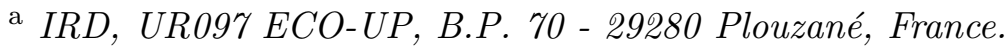 \\ b IRD, UMR065 LEGOS, 101 Promenade Roger Laroque - Anse Vata, B.P. A5, \\ 98848 Nouméa Cedex, Nouvelle-Calédonie. \\ c INRIA, Laboratoire Jean Kuntzmann, Grenoble, France.
}

\begin{abstract}
ROMSTOOLS, a collection of global datasets and a series of Matlab programs collected in an integrated toolbox, generates the grid, surface forcing, initial condition, open boundary conditions, and tides for climatological and inter-annual ROMS ocean simulations. ROMSTOOLS generates also embedded models, realtime coastal modeling systems, as well as experiments including biology. Tools for visualization, animations and diagnostics are also provided.
\end{abstract}

Key words: Ocean Models, Numerical simulation, Regional Modeling, Coastal Oceanography, Embedding

* Corresponding author. Tel +33 (0)2 98224513 Fax +33 (0)2 98224514 Email address: Pierrick.Penven@ird.fr (Pierrick Penven).

Preprint submitted to Elsevier Science

16 July 2007 


\section{Software availability}

Software name: ROMSTOOLS

Contact: Pierrick.Penven@ird.fr

Software required: Linux or Unix, Matlab

Program language: Matlab

Availability: free (GNU General Public license) from http://www.brest.ird.fr/Roms_tools/

\section{Introduction}

ROMS is a parallel, free surface, topography following, hydrostatic, primitive equation model (Shchepetkin and McWilliams, 2005) with robust open boundaries, grid refinement, sediment and ecosystem modules. ROMS robustness allows now to follow a systematic approach to obtain regional ocean simulations. ROMSTOOLS, a collection of global datasets and Matlab programs in an integrated toolbox, provides ROMS input data (horizontal and vertical grids, bottom topography, surface forcing, initial conditions and boundary conditions). A documentation is available (Penven and Tan, 2007).

\section{Software description}

For simplicity, ROMSTOOLS generates rectangular Mercator grids. Bathymetry $(h)$ is derived from ETOPO2. An iterative averaging procedure is applied to prevent under-sampling. To prevent pressure gradient errors, $h$ is smoothed to reduce a "slope parameter" $r=\frac{\left|h_{+1 / 2}-h_{-1 / 2}\right|}{\left|h_{+1 / 2}+h_{-1 / 2}\right|}$. Since $r \sim \frac{\nabla h}{h}$, a modified Shapiro smoother is applied iteratively on $\log (h)$ where $r$ is above the required value 
(generally 0.25 ). For a typical continental slope and a shelf $O(100) \mathrm{km}$ wide, filtering induced errors are below $2 \%$ if the grid is finer than $4 \mathrm{~km}$. Land-sea masking is generated from the unfiltered topography.

Surface forcing are derived from COADS. Missing values are replaced by objective analysis. The resulting matrices are interpolated using a cubic method. The model sea surface temperature (SST) feedback on the heat flux is represented as a correction towards COADS SST. A similar correction is used for the fresh water flux. QuikSCAT, a finer wind stress monthly climatology, and Pathfinder, a finer SST climatology can be employed alternatively. COADS can also force an air-sea bulk parametrization.

Model initialization uses WOA hydrography and no flow. For each WOA zlevel, missing values are replaced by objective analysis. The resulting matrices are horizontally, and subsequently vertically, interpolated on the ROMS terrain-following grid.

WOA hydrography and WOA geostrophic (+ COADS Ekman) velocities (a level of no motion is defined) force ROMS open boundary conditions. A global mass conservation constraint is applied. Equatorial currents are approximated from non-equatorial values.

For tidal runs, tidal constituents are interpolated from TPXO6: high frequency currents and elevations are added to the low frequency boundary conditions via a Flather (1976) condition.

For inter-annual runs, ROMSTOOLS uses ECCO or SODA for initial and boundary conditions, and NCEP/NCAR as surface forcing. To limit downloading time, ROMSTOOLS uses OPeN_DAP to get only the necessary sub- 
grids. A several years spin-up can be made by cycling on the first year. Daily QuikSCAT winds can also be used.

For nesting, a GUI generates the input files for each embedding level. Child domains can be "hot started" after the parent model spin-up.

For ecosystem runs, WOA provides nitrate. SeaWIFS surface chlorophyll is vertically extrapolated using Morel and Berthon (1989) parameterization. Phytoplankton and zooplankton are estimated as $[$ phyto $] \sim 0.5 \times[$ chla $]$ and $[z o o] \sim 0.2 \times[$ chla $]$. Since these models are largely controlled by nitrate, the last 3 estimations have a limited impact.

For real-time runs, ROMSTOOLS assumes that large-scale dynamics are slow compared to coastal systems. The latest ECCO outputs available are used as boundary conditions. GFS is used as surface forcing.

A GUI displays ROMS variables for any horizontal level and computes derived properties as well as times series, vertical profiles, vertical sections and Hovmller diagrams. Time series and statistics are computed for long simulations

\section{Conclusion}

With ROMSTOOLS, few parameter are required to create ROMS simulations: resolution, number of vertical levels, topography smoothing and a level of nomotion for the open boundaries currents. For portability and accessibility, ROMSTOOLS is based on Matlab: model preparations, analysis and visualizations are made within a single framework. In the future, ROMSTOOLS could be adapted to other ocean models such as pPOM (Giunta, 2007). 


\section{References}

Flather, R. A., 1976. A tidal model of the Northwest European continental shelf. Mémoires de la Société Royale des Sciences de Liège 10, 141-164.

Giunta, G., Mariani, P., Montella, R., Riccio, A., 2007. pPOM: A nested, scalable, parallel and Fortran 90 implementation of the Princeton Ocean Model. Environ. Model. Soft. 22, 117-122.

Morel, A., Berthon, J.-F., 1989. Surface pigments, algal biomass profiles, and potential production of the euphotic layer: Relationships reinvestigated in view of remote-sensing applications. Limnol. Oceanogr. 34, 1545-1562.

Penven, P., Tan, T., 2007. ROMSTOOLS user's guide http://www. brest. ird. fr/roms_tools. Tech. rep., IRD.

Shchepetkin, A. F., McWilliams, J. C., 2005. The regional oceanic modeling system (ROMS): a split-explicit, free-surface, topography-followingcoordinate oceanic model. Ocean Model. 9, 347-404.

\section{A Appendix: datasets used by ROMSTOOLS}

- ETOPO2 is a global topography (2' resolution) derived from depth soundings and satellite gravity observations (Smith and Sandwell, 1997. Global sea floor topography from satellite altimetry and ship depth soundings. Science 277, 1957-1962).

- The Atlas of Surface Marine Data (COADS) is a monthly climatology $\left(0.5^{\circ}\right.$ and $1^{\circ}$ resolution) of air-sea parameters derived from individual observations (Da Silva et al., 1994. Atlas of surface marine data 1994, vol. 1, algorithms and procedures. Tech. rep., U. S. Department of Commerce, NOAA).

- The World Ocean Atlas 2005 (WOA) is a monthly climatology ( $1^{\circ}$ resolution, 
33 vertical levels) of in-situ ocean parameters derived from individual observations (Conkright et al., 2002. World Ocean Atlas 2001: Objective analyses, data statistics, and figures, CD-ROM documentation. Tech. rep., National Oceanographic Data Center, Silver Spring, MD).

- The QuikSCAT monthly climatology was computed from QuikSCAT gridded data (0.5 resolution) from Oct 1999 to Aug 2006 (Liu et al., 1998. Nasa scatterometer provides global ocean-surface wind fields with more structures than numerical weather prediction. Geophys. Res. Lett. 25, 761-764).

- Pathfinder is a monthly climatology of SST (9.28 km resolution) derived from AVHRR observations from 1985 to 1997 (Casey and Cornillon, 1999. A comparison of satellite and in situ based sea surface temperature climatologies. J. Clim. 12, 1848-1863).

- The SeaWIFS seasonal climatology of phytoplankton pigment concentrations is generated by the NASA Goddard Space Flight Center (Feldman and McClain, 2006. SeaWIFS reprocessing 5, http://oceancolor.gsfc.nasa.gov/).

- TPXO6 is a global model $\left(0.25^{\circ}\right.$ resolution $)$ of ocean tides assimilating satellite altimetry (Egbert and Erofeeva, 2002. Efficient inverse modeling of barotropic ocean tides. J. Atm. Ocean. Tech. 19, 183-204).

- ECCO is a near-global $\left(78^{\circ} \mathrm{S}-78^{\circ} \mathrm{N}\right)$ ocean model $\left(1^{\circ}\right.$ resolution, 46 vertical levels) forced by NCEP/NCAR (Stammer et al., 1999. The consortium for estimating the circulation and climate of the ocean (ECCO). Tech. rep., JPL - MIT - SIO). SSH is assimilated using a Kalman filter. ECCO is available from 1993 until present.

- SODA is a global ocean model $\left(0.25^{\circ} \times 0.4^{\circ}\right.$ resolution, 40 vertical levels $)$ forced by ERA-40 (Carton et al., 2005. Sea level rise and the warming of the oceans in the Simple Ocean Data Assimilation (SODA) ocean reanalysis. J. Geophys. Res. 110, C09006). Hydrography, SST and SSH are sequentially as- 
similated. Monthly data are available on a $0.5^{\circ}$ grid from 1958 until 2001.

- The NCEP/NCAR reanalysis is based on a global T62 spectral atmospheric model ( $\sim 210 \mathrm{~km}$ resolution) with $28 \sigma$-levels on a $1.875^{\circ}$ grid from 1948 until present (Kistler et al., 2001. The NCEP/NCAR 50-year reanalysis: Monthly means CD-ROM and documentation. Bull. Am. Meteorol. Soc. 8, 247-268). Atmospheric data are assimilated using a 3D variational scheme.

- GFS is a global T382 spectral atmospheric model ( $\sim 40 \mathrm{~km}$ resolution) with $64 \sigma$-levels (Kanamitsu et al., 1991. Recent changes implemented into the global forecast system at NMC. Wea. and Forecasting 6, 425-435). It is run to 7.5 days, four times per day. 